\title{
Histological Evaluation of Bioresorbable Threads in Rats
} \author{
Min Hi $\operatorname{Sin}^{4}$, Hyun Ho Kim ${ }^{5}$ Ki-Jong Rhee ${ }^{1}$ \\ ${ }^{5}$ NEO Dr. Inc., Wonju, Korea
}

Chang Gun Lee ${ }^{1}$, Jaeyun Jung ${ }^{2}$, Samnoh Hwang ${ }^{3}$, Chan Oh Park ${ }^{1}$, Soonjae Hwang ${ }^{1}$, Minjeong Jo ${ }^{1}$,

\section{랫드에서의 생분해성 매선요법에 대한 조직학적 분석}

\author{
이창근 ${ }^{1}$, 정재윤 ${ }^{2}$, 황삼노 $^{3}$, 박찬오 $^{1}$, 황순재 $^{1}$, 조민정 ${ }^{1}$, 신민희 $^{4}$, 김현호$^{5}$, 이기종 ${ }^{1}$ \\ ${ }^{1}$ 연세대학교 보건과학대학 임상병리학과, ${ }^{2}$ 미엘르의원, ${ }^{3}$ 가톨릭대학교 서울성모병원 병리과, ${ }^{4}$ 원주세브란스기독병원 병리과, ${ }^{5}$ (주)네오닥터
}

\begin{abstract}
Thread lifting has become popular as a minimally invasive technique for facial rejuvenation. Commercially available threads are composed of poly-L-lactic acid (PLLA), polycaprolactone (PCL), or polydioxanone (PDO). However, the histological changes that occur in response to implanted threads are unclear. The aim of this study was to evaluate histological changes that occur in response to implantation with three types of bioresorbable threads (PLLA, PCL, PDO) in rat skin. PLLA, PCL and PDO threads were implanted in the dorsal skin of Sprague Dawley rats and tissue samples were harvested 2, 4, 8 and 12 weeks post-implantation. To evaluate histologic changes induced by bioresorbable face-lifting threads, tissue samples were stained with hematoxylin \& eosin, Masson's trichrome stain and Herovici's collagen stain. All three threads induced neocollagenesis of type 3 collagen in the rat skin. The amount of collagen induced by the threads was dependent on the thread surface area. The PDO cavern-type thread was most effective in inducing neocollagenesis due to its extensive surface area. Our results suggest that type 3 collagen induced by bioresorbable threads depends on the thread surface area to uphold the dermis and contributes to facial rejuvenation.
\end{abstract}

Key words: Collagen, Polydioxanone, Rat, Skin

This is an Open Access article distributed under the terms of the Creative Commons Attribution Non-Commercial License (http://creativecommons.org/licenses/by-nc/4.0) which permits unrestricted non-commercial use, distribution, and reproduction in any medium, provided the original work is properly cited.

Copyright @ 2018 The Korean Society for Clinical Laboratory Science. All rights reserved.
Corresponding author: Ki-Jong Rhee Department of Biomedical Laboratory Science, College of Health Sciences, Yonsei University, 1 Yonseidae-gil, Wonju 26493, Korea Tel: 82-33-760-2445 Fax: 82-33-760-2195 E-mail: kjrhee@yonsei.ac.kr

Received: August 14, 2018 Revised: August 29, 2018 Accepted: September 3, 2018

\section{INTRODUCTION}

The increase in the proportion of the senior population in Korea has resulted in intense interest in anti-aging procedures. One prominent feature of aging is facial aging. Facial aging results from a combination of skeletal and non-skeletal soft-tissue changes that manifest as universally recognizable patterns. Key changes that occur during facial aging include progressive soft-tissue laxity and volume loss which manifests in the form of brow ptosis, deepening of nasolabial folds, jowl formation and orbital rim prominence [1]. Traditional facial rejuvenation techniques include invasive surgical procedures as well as non-invasive surgical procedures such as laser resurfacing, chemical peels, injection of neurotoxins and injection of dermal fillers [2]. Surgical procedures require meticulous, 
and in many cases, extensive dissection of the superficial muscular aponeurotic system and involves a prolonged recovery period. To that end, the superficial musculoaponeurotic system (SMAS) facelift is considered the gold standard for patients undergoing facial rejuvenation [3, 4]. However, less invasive nonsurgical techniques to treat ptotic skin have been proposed as alternative treatments [5].

Thread lifting has become popular as a minimallyinvasive procedure for rejuvenation of facial skin and the underlying soft tissue. This technique was primarily developed to suspend the sustainable tissues, such as the malar fat pad, without open surgery [6]. Thread-lifting remodels the sagging skin on the face using surgical suture threads. The greatest advantage of a thread-lift is the absence of visible scars and a very short recovery period. Previously, thread-lifts were performed with permanent sutures but now they are mostly performed with dissolvable sutures that disappear within several months. The thread-lift procedure involves inserting a threaded needle under the skin after local anesthesia. The shape, thickness and materials of the threads differ, depending on the preference of the surgeon and the needs of the patient. Generally, 2 30 threads are inserted per procedure. Once the threads are embedded into the skin, formation of new collagen fibers and elastic fibers ensues, resulting in increased collagen and elastin volume. In addition, cells produce more hyaluronic acid in response to the threads with concomitant increase in water retention. Collectively, this fibrosis process results in a visibly youthful skin.

The most commonly used threads are composed of bioresorbable materials such as poly-L-lactic acid (PLLA), polycaprolactone (PCL) or polydioxanone (PDO). Although several advantages and disadvantages are thought to exist for each type of thread, the cosmetic surgeon's preference appears to be a major factor for deciding the type of thread used during a facial thread-lifting procedure. Although the scientific literature contains numerous reports on the biocompatibility and host responses to these compounds in both animals and humans, a systematic and comprehensive comparison of PLLA, PCL and PDO in terms of collagen and elastic fiber formation to each of these thread types is lacking. In the present study, we compared the tissue response in rats to PLLA, PCL and PDO threads using hematoxylin and eosin (H\&E), Masson's trichrome and Herovici's stains. In addition, we further compared the tissue response to three different PDO threads of different thickness and shape using Masson's trichrome stain.

\section{MATERIALS AND METHODS}

\section{Animal experiments}

Eight-week-old female Sprague Dawley (SD) rats were purchased from Raonbio (Yongin, Korea). The rats were maintained in a filter-top cage with a 12-h light/12-h dark cycle. Sterile food pellets (Teklad-certified irradiated global 18\% protein rodent diet 2018S; Harlan Teklad, Madison, WI, USA) and autoclaved water were provided ad libitum. Rats were anesthetized, dorsal area shaved and implantation points marked prior to thread insertion (Figure 1). Four identical threads were inserted in parallel into the panniculus carnosus via needles. The needles were then immediately removed along with any exposed thread. $3 \sim 5$ rats were used per thread for each time point. Tissue samples from surrounding subcutaneous tissue, along with the thread, were harvested for histologic analysis at 2, 4, 8 and 12 weeks after implantation. Rats exhibited no gross signs of inflammation in the insertion area during the experimental period. All experiments
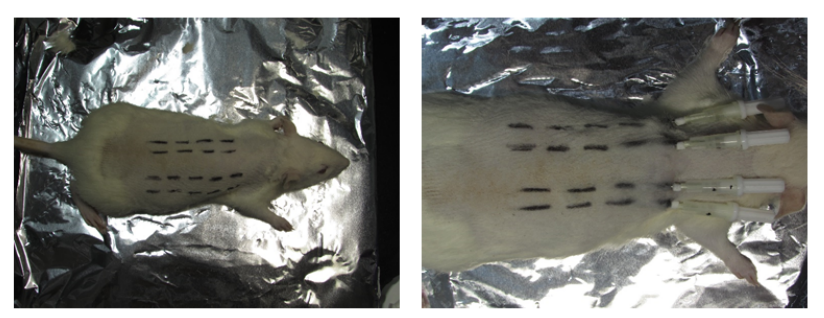

Figure 1. Thread implantation in rats. Eight-week-old female Sprague Dawley (SD) rats were anesthetized, dorsal area shaved and injection points marked prior to thread insertion (left panel). Each rat was inserted with four identical threads in parallel into the panniculus carnosus via needles (right panel). The needles were then immediately removed along with any exposed thread. $3 \sim 5$ rats were used per thread for each time point. Rats exhibited no gross signs of inflammation in the insertion area during the experimental period. 
were conducted in accordance with the guidelines of the Institutional Animal Health Care and Use Committee (IACUC) of Yonsei University at Wonju (YWCI-201702001-02).

\section{Thread types}

Five different kinds of bioresorbable threads were evaluated. One type of PLLA monothread (APROMEDION, Cat No: NSC-PL6-2938, Korea), one type of PCL monothread (Ultra V, Cat No: MR-CB29306, Korea) and three types of PDO threads (NEO Dr. Inc., Korea). Suture thickness is defined by the United States Pharmacopeia (USP). The 29G PLLA monothread and 29G PCL monothread (6-0 USP, $0.07 \mathrm{~mm}$ in diameter, $50 \mathrm{~mm}$ in length) is contained within a 29G needle. Three types of PDO monothreads were evaluated; 29G PDO monothread (Cat No: ND2903860M, 6-0 USP, $0.07 \mathrm{~mm}$ in diameter, $50 \mathrm{~mm}$ in length) contained within a 29G needle, 19G PDO monothread (Cat No: ND1903801M, 1 USP, $0.4 \mathrm{~mm}$ in diameter, $25 \mathrm{~mm}$ in length) contained within a 19G needle and the cavern-type 29G PDO (Cat No: ND2905060CVS, 6-0 USP, $0.07 \mathrm{~mm}$ in diameter, $20 \mathrm{~mm}$ in diameter) contained within a 29G needle. The cavern-type needle contains $40 \mathrm{~mm}$ of monothread in a spiral-shaped structure with a final length of $20 \mathrm{~mm}$.

\section{Histologic analysis}

Tissue specimens were fixed with 10\% formalin and embedded in paraffin. Transverse sections $(5 \mu \mathrm{m})$ along the thread axis were obtained. Tissues were deparaffinized with xylene, rehydrated with ethanol and stained with standard H\&E stain for overall histologic evaluation. Masson's trichrome stain was performed for detection of collagen. Masson's trichrome stain was performed by the following procedure. After deparaffinization of slides, Boüin solution (Sigma) was applied for 30 minutes at $56^{\circ} \mathrm{C}$. The slides were washed and treated with Weigert hematoxylin (Merck) for 10 minutes. Biebrich scarlet-acid fuchsin (Sigma) was applied for 10 minutes, then 3 minutes of treatment with phosphotungstic-phosphomolybdic acid solution (Sigma). Finally, collagen was stained with light green solution (Sigma) for 8 minutes. Verhoeff's elastic fiber stain was performed for detection of elastic fibers. To discern collagen subtypes, tissues were stained

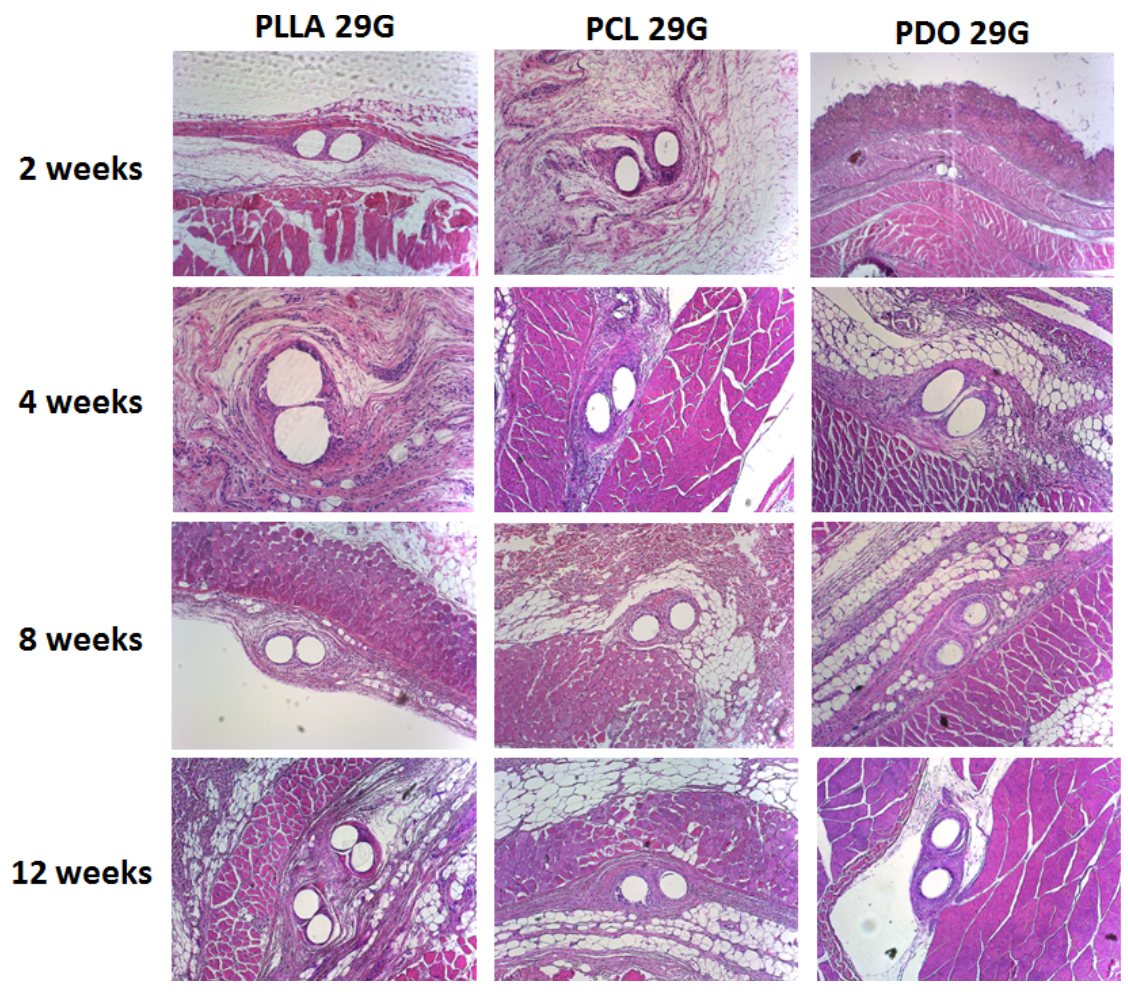

Figure 2. H\&E staining of tissues implanted with PLLA, PCL and PDO threads. Tissue samples of the dorsal subcutaneous tissue were harvested and stained with H\&E. Histologic analysis was performed at 2, 4, 8 and 12 weeks after implantation with PLLA, PCL and PDO threads. 3 5 rats were used per thread for each time point. Threads are depicted as white, empty circular regions. Representative images are shown. Magnification, $\times 100$. 
with Herovici's stain using Herovici's collagen staining kit (American MasterTech). After tissue staining, slides were photographed by optical microscopy (Leica, Wetzlar, Germany) and rendered using Leica software.

\section{RESULTS}

\section{H\&E staining of tissues implanted with PLLA, PCL and PDO threads}

To investigate the histologic changes after implantation of the PLLA, PCL and PDO monothreads, rats were inserted with the respective threads and the dorsal skin tissues harvested and stained with H\&E 2, 4, 8 and 12 weeks after implantation (Figure 2). The threads are not compatible with the H\&E staining and thus appear as empty circles encircled by a fibrous sheath. The PDO thread implantation sites showed a thin capsular structure surrounding the thread by 2 weeks which gradually thickened by 12 weeks. Prominent tissue reactions showed the aggregation of inflammatory cells and fibroblasts surrounding the suture thread. The overlying epidermis showed no prominent changes after implantation.
No other significant pathological features were noted surrounding the PDO thread. Similar results were obtained for PLLA and PCL, suggesting that no gross differences were present after insertion of the three thread types.

\section{Masson's trichrome staining of tissues implanted with PLLA, PCL and PDO threads}

Collagen formation induced by inserted threads provides a youthful appearance in patients and thus the ability of threads to enhance neocollagenesis is one key factor in evaluating the efficacy of thread procedures. To determine neocollagenesis induced by PLLA, PCL and PDO threads, tissues were examined by Masson's trichrome staining at 2, 4, 8 and 12 weeks after implantation. The fibrous sheaths surrounding each thread type contained relatively similar amounts of collagen (Figure 3). Although a quantitative assessment of collagen levels is beyond the scope of this study, the collagen levels in the immediate vicinity of the threads appeared to be higher than collagen levels present in the overlying skin. Regardless, the amount of collagen induction in the three type of threads were similar during the 12 -week period in rats.
2 weeks
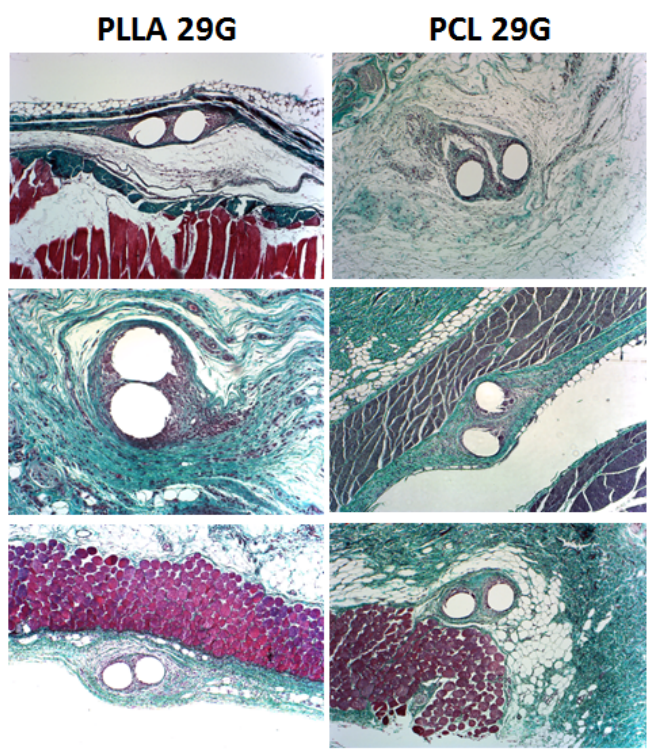

8 weeks

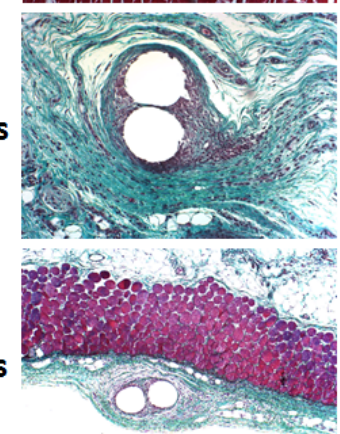

4 weeks

\section{(1)}

12 weeks

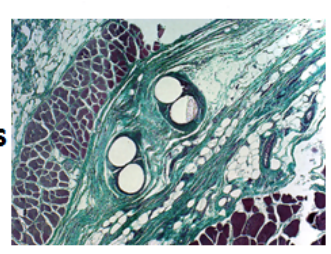

PDO 29G

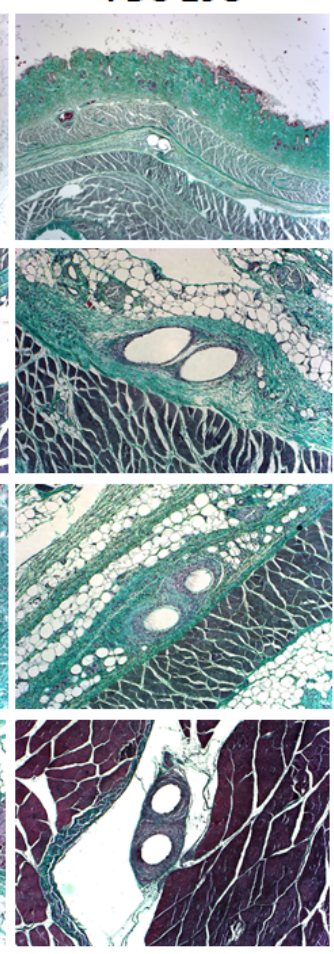

Figure 3. Masson's trichrome staining of tissues implanted with PLLA, PCL and PDO threads. Tissue samples of the dorsal subcutaneous tissue were harvested and stained with Masson's trichrome stain. Histologic analysis was performed at 2, 4, 8 and 12 weeks after implantation with PLLA, $\mathrm{PCL}$ and $\mathrm{PDO}$ threads. 3 5 rats were used per thread for each time point. Threads are depicted as white, empty circular regions. Representative images are shown. Magnification, $\times 100$. 


\section{Herovici's staining of tissues implanted with PLLA,} PCL and PDO threads

Masson's trichrome staining of rat tissues shows increased collagen surrounding the threads. Collagen is categorized into many types with minor structural and functional differences as well as different distributions [7, 8]. Therefore, we next examined the type of collagen that was formed upon thread implantation using Herovici's staining which discerns type 1 collagen (red/purple) and type 3 collagen (blue). We found that PLLA, PCL and PDO threads induced predominantly type 3 collagen in the rat's dermal skin layer at all of the time points examined (Figure 4). Dermal elastic fibers are believed to have a primary role in providing elastic stretch and recoil to the skin, so we analyzed by Verhoeff's staining whether the thread-lifting can induce elastic fiber formation. However, there were no signs of elastic fiber formation during the implantation period (data not shown). These results suggest that the three thread types induced comparable levels of predominantly type 3 collagen in rats.

\section{Masson's trichrome staining of tissues inserted with 29G PDO, 19G PDO and cavern-type PDO}

Threads of different diameters are commercially available and the diameter is selected based on the specific application of target areas. We examined the ability of the cavern-type PDO thread on formation of neocollagenesis. The cavern-type PDO thread is a single monothread that has a spiral shape. This results in implantation of more thread material with a single injection. The rationale for using the cavern-type PDO thread is that fibrosis is elicited on contact with the biodegradable thread and thus inserting more thread material should increase more collagen. Indeed, rats injected with the cavern-type PDO thread showed numerous empty circles indicative of multiple thread insertions compared with single encapsulations induced by 29G PDO and 19G PDO (Figure 5).

\section{DISCUSSION}

Bioresorbable implantation materials have gained popularity and with demonstrated safety in the clinical
2 weeks

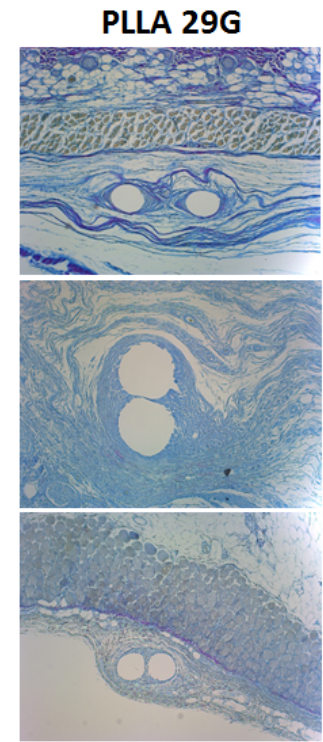

12 weeks
PCL 29G
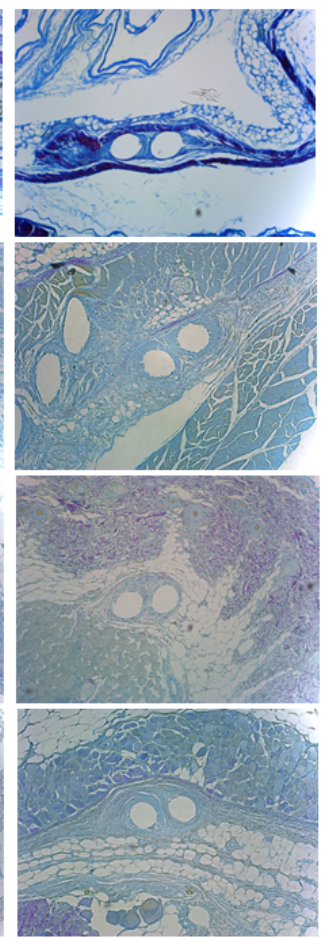

PDO 29G

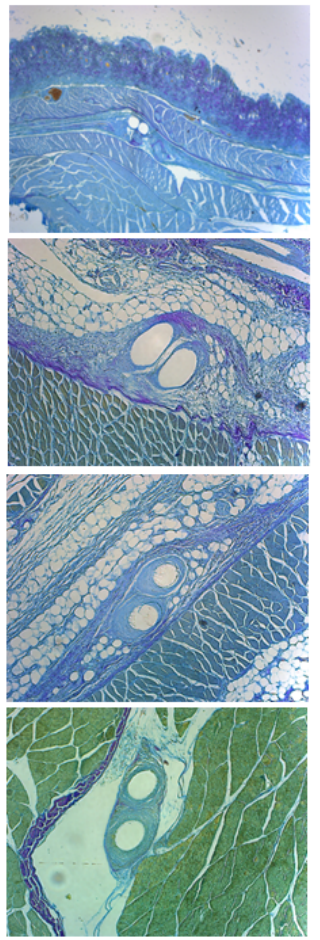

Figure 4. Herovici's staining of tissues implanted with PLLA, PCL and PDO threads. Tissue samples of the dorsal subcutaneous tissue were harvested and stained with Herovici's stain. Histologic analysis was performed at 2, 4, 8 and 12 weeks after implantation with PLLA, PCL and PDO threads. $3 \sim 5$ rats were used per thread for each time point. Threads are depicted as white, empty circular regions. Representative images are shown. Magnification, $\times 100$. 


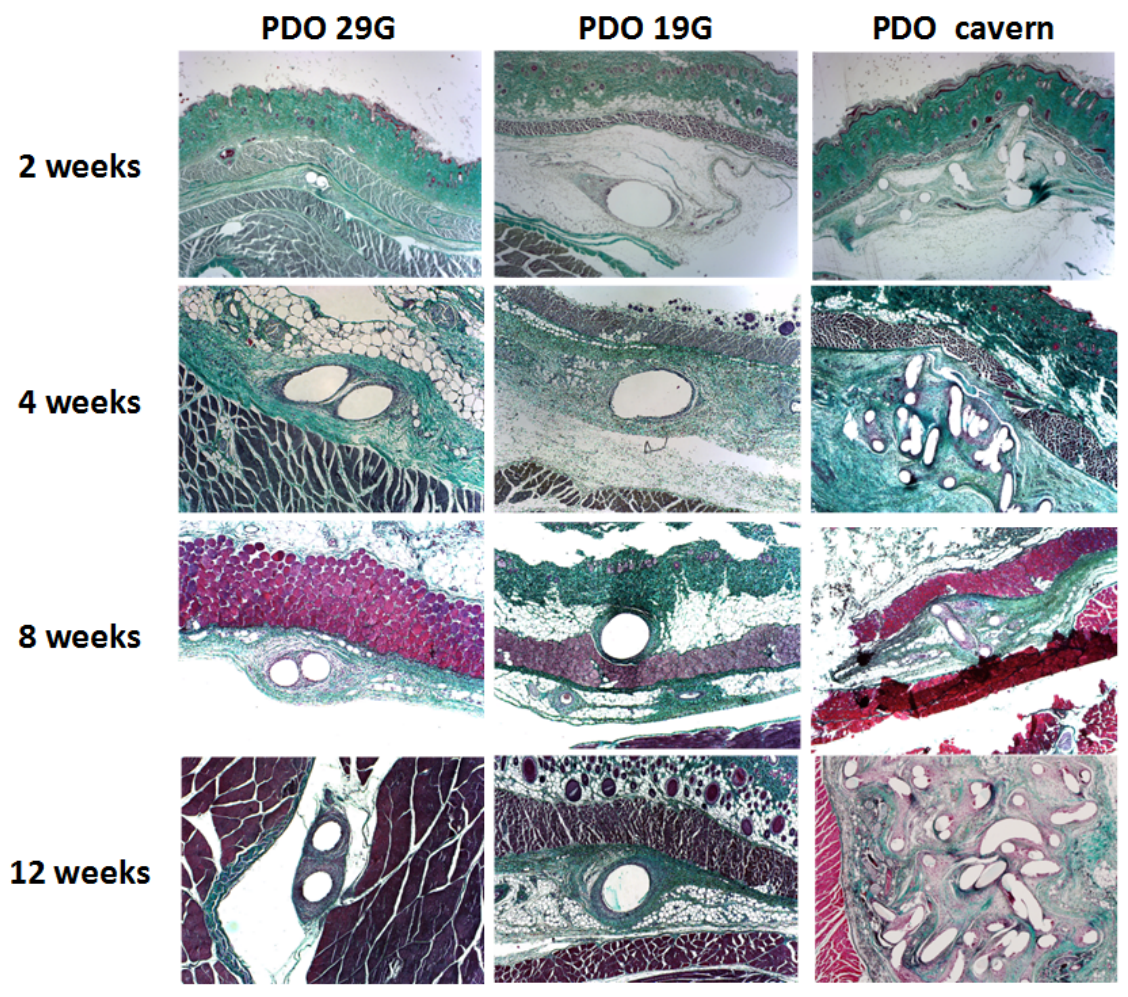

Figure 5. Masson's trichrome staining of tissues inserted with 29G PDO, $19 G$ PDO and cavern-type PDO. Tissue samples of the dorsal subcutaneous tissue were harvested and stained with Masson's trichrome stain. Histologic analysis was performed at $2,4,8$ and 12 weeks after implantation with 29G PDO, 19G PDO and cavern-type 29G PDO threads. 3 5 rats were used per thread for each time point. Threads are depicted as white, empty circular regions. Numerous cavern-type PDO threads are depicted. Representative images are shown. Magnification for $29 \mathrm{G}$ PDO and 19G PDO, $\times 100$. Magnification for cavern-type PDO, $\times 40$. setting. The popular PDO suture is a colorless bioresorbable artificial polymer which shows minimal long term side effects after implantation. PDO has been used for surgical suture and cosmetic surgery due to its biocompatibility, flexibility, and elasticity [9, 10]. Other commonly used suture materials are PLLA and PCL. However, there are several documented case reports on the deleterious side effects of PDO as well as PLLA after thread implantation. In one report, granulomatous inflammation with neutrophilic abscess in the dermis was reported after a PDO thread-lift procedure due to Mycobacterium massiliense infection [11]. In another case, erythematous nodules in the temple was reported after PLLA thread procedure due to infection by methicillin-resistant Staphylococcus aureusinfection [12]. Generally, the vast majority of thread-lifting procedures are safe and the aforementioned documented cases were likely due to rare complications occurring during the thread-lift procedure. In our current study, we observed no adverse infections in the rat skin by all three threads after implantation.

PDO is a colorless bioresorbable artificial polymer which undergoes complete hydrolytic degradation in vivo depending on the implantation site and diameter of the suture. In our current study, a subset of rats was implanted with PDO for up to 8 months. The PDO thread was visible in tissue sections for up to 6 months but completely absorbed within 8 months (data not shown). The PLLA and PCL thread was visible in tissue sections even up to 8 months (data not shown). During the experimental time frame, all three thread types induced comparable levels of collagen. The extent of collagen formation appeared to be dependent on the surface area of the thread. Since the cavern-type PDO thread is spiral-shaped, more thread material is incorporated into the skin and thus more collagen is induced surrounding the thread implantation site. Although multiple insertions would theoretically confer similar effects, a single injection of would be preferable to the patient undergoing thread-lifting procedure.

Collagen is the most abundant protein produced in humans and is fundamental in contiguous formation of the interstitium in the skin. In human skin, type 1 and type 3 collagens are found at a higher proportion compared to other types of collagen. During scar tissue formation during injury or other insults, alteration of the relative 
proportions of type 1 and type 3 collagen may occur [13]. Both the abundance and balance of type 1 and type 3 collagen have received considerable attention [14, 15]. Herovici developed a staining technique in 1963 to distinguish between type 1 and type 3 collagen [16]. The Herovici stain has been used to differentiate and quantify the amount of type 1 and type 3 collagen within mature burn scars, keloid scars and Dupuytren's contractures [17-19]. Recently, Ko et al [20] found that thread implantation induced type 3 collagen in pigs. In our current experiment, all three thread types induced predominantly type 3 collagen in rats. However, none of the three bioresorbable threads induced elastic fiber formation as determined by Verhoeff's staining (data not shown). In conclusion, our comparative studies showed that PLLA, PCL and PDO threads induced comparably levels of type 3 collagen in rat skin.

\section{요 약}

매선요법은 다른 시술에 비해 비침습적이고, 인체 내에서 생 분해가 일어나는 물질로 제작되기 때문에 성형수술에서 각광받 고 있다. 상업적으로 이용가능한 매선의 종류로는 poly-L-lactic acid (PLLA), polycarprolactone (PCL), polydioxanone (PDO) 등이 있으나, 매선으로 사용되는 생분해성 물질들의 종 류에 따른 차이점이나, 콜라겐을 형성하는데 있어서 매선의 어 떤 부분이 결정적으로 작용하는지에 대한 연구는 잘 알려져 있 지 않다. 따라서 이 연구에서는 현재 판매되고 있는 3 가지 생분 해성 물질(PLLA, PCL, PDO)로 만들어진 매선을 동물모델에서 그 효과를 비교하고, 매선의 콜라겐생성능에 미치는 영향 인자 가 무엇인지를 분석하였다. 매선을 랫드의 등에 삽입하여 2주, 4 주, 8 주, 12 주동안 경과를 관찰하고 특수염색을 통해 콜라겐 의 생성 정도를 비교하였다. 매선에 의한 조직학적 변화를 관찰 하기 위해서, 조직검체는 H\&E, Masson's trichrome, Herovici's collagen stain이 진행되었다. 그 결과 3 가지 모두 다 동일한 시기에 비슷한 양의 신생콜라겐을 형성하는 것을 관 찰할 수 있었고, 3 가지 매선 모두 type 3 의 콜라겐을 형성하는 것을 확인할 수 있었다. 또한 생성되는 콜라겐의 양은 매선이 피 부조직에 닿는 면적이 크면 클수록 증가하는 것을 관찰할 수 있 어 한 번의 시술만으로도 많은 양의 매선이 들어갈 수 있는 PDO cavern타입의 매선이 가장 많은 콜라겐을 형성하는 것을 확인
할 수 있었다.

Acknowledgements: Following results of a study are on the "Leaders in Industry-university Cooperation+" (LINC+) project, supported by the Ministry of Education and National Research Foundation of Korea (2017-DG043-010103) to K.-J.R. C.G.L. (Graduate Student); J.J. (Medical Doctor), S.H. (Medical Technologist), C.O.P. (Graduate Student); S.H. (Graduate Student), M.J. (Graduate Student), M.H.S. (Medical Technologist), H.H.K. (CEO) and K.-J.R. (Professor).

Conflict of interest: Hyun Ho Kim is the current CEO of NEO Dr. Inc. All other authors have no conflict of interest to declare.

\section{REFERENCES}

1. Abraham RF, DeFatta RJ, Williams EF. Thread-lift for facial rejuvenation: assessment of long-term results. Arch Facial Plast Surg. 2009;11:178-183.

2. Karimi K, Reivitis A. Lifting the lower face with an absorbable polydioxanone (PDO) thread. J Drugs Dermatol. 2017;16: 932-934.

3. Baker D. Rhytidectomy with lateral SMASectomy. Facial Plast Surg. 2000;16:209-213.

4. Liu TS, Owsley JQ. Long-term results of face lift surgery: patient photographs compared with patient satisfaction ratings. Plast Reconstr Surg. 2012;129:253-262.

5. Ogilvie MP, Few JW, Tomur SS, Teven CM, Semersky AJ, Bruno $\mathrm{CR}$, et al. Rejuvenating the face: an analysis of 100 absorbable suture suspension patients. Aesthet Surg J. 2018;38:654-663.

6. Kurita M, Matsumoto D, Kato H, Araki J, Higashino T, Yoshimura K, et al. Tissue reactions to cog structure and pure gold in lifting threads: a histological study in rats. Aesthet Surg J. 2011;31:347-351.

7. Pawelec KM, Best SM, Cameron RE. Collagen: a network for regenerative medicine. J Mater Chem B. 2016;4:6484-6496.

8. Watt FM, Fujiwara H. Cell-extracellular matrix interactions in normal and diseased skin. Cold Spring Harb Perspect Biol. 2011;3. pii: a005124. doi: 10.1101/cshperspect.a005124.

9. Uff CR, Scott AD, Pockley G, Phillips RKS. Influence of soluble suture factors on in vitro macrophage function. Biomaterials. 1995;16:355-360.

10. Smith MJ, White KL, Smith DC, Bowlin GL. In vitro evaluations of innate and acquired immune responses to electrospun polydioxanone-elastin blends. Biomaterials. 2009;30:149-159.

11. Shin JJ, Park JH, Lee JM, Ryu HJ. Mycobacterium massiliense infection after thread-lift insertion. Dermatol Surg. 2016;42: 1219-1222.

12. Choi M, Cheon JS, Choi WY, Son KM. Late-onset methi- 
cillin-resistant Staphylococcus aureus infection after facial poly-1-lactic acid injection. Arch Plast Surg. 2017;44:248-249.

13. Cheng W, Rong YH, Ning FG, Zhang GA. The content and ratio of type I and III collagen in skin differ with age and injury. African Journal of Biotechnology. 2011;10:2524-2529.

14. Feng J, Hu T, Liu W, Zhang S, Tang Y, Wei F, et al. The biomechanical, morphologic, and histochemical properties of the costal cartilages in children with pectus excavatum. J Pediatr Surg. 2001;36:1770-1776.

15. Weber L, Kirsch E, Muller P, Krieg T. Collagen type distribution and macromolecular organization of connective tissue in different layers of human skin. J Invest Dermatol. 1984;82: 156-160.

16. Levame M, Meyer F. Herovici's picropolychromium. Application to the identification of type I and III collagens. Pathol Biol (Paris). 1987;35:1183-1188.
17. Rawlins JM, Lam WL, Karoo RO, Naylor IL, Sharpe DT. Quantifying collagen type in mature burn scars: a novel approach using histology and digital image analysis. J Burn Care Res. 2006;27:60-65.

18. Syed F, Ahmadi E, Iqbal SA, Singh S, McGrouther DA, Bayat A. Fibroblasts from the growing margin of keloid scars produce higher levels of collagen I and III compared with intralesional and extralesional sites: clinical implications for lesional site-directed therapy. Br J Dermatol. 2011;164:83-96.

19. Lam WL, Rawlins JM, Karoo ROS, Naylor I, Sharpe DT. Re-visiting Luck's classification: a histological analysis of Dupuytren's disease. J Hand Surg Eur Vol. 2010;35:312-317.

20. Ko HJ, Choi JY, Moon HJ, Lee JW, Jang SI, Kim BJ, et al. Multi-polydioxanone (PDO) scaffold for forehead wrinkle correction: a pilot study. J Cosmet Laser Ther. 2016;18:405-408. 